Research

\title{
The distribution of hatching time in Anopheles gambiae
} Alpha S Yaro ${ }^{1}$, Adama Dao', Abdoulaye Adamou ${ }^{1}$, Jacob E Crawford ${ }^{2}$, José MC Ribeiro ${ }^{2}$, Robert Gwadz², Sekou F Traoré ${ }^{1}$ and Tovi Lehmann*2

\author{
Address: ${ }^{1}$ Malaria Research and Training Center, 1805, Point G. Bamako, Mali and ${ }^{2}$ Laboratory of Malaria and Vector Research, NIAID, NIH. 12735 \\ Twinbrook Parkway, Rockville, MD, USA \\ Email: Alpha S Yaro - yaro@mrtcbko.org; Adama Dao - adama@mrtcbko.org; Abdoulaye Adamou - adamou@mrtcbko.org; \\ Jacob E Crawford - crawfordj@niaid.nih.gov; José MC Ribeiro - jribeiro@niaid.nih.gov; Robert Gwadz - rgwadz@niaid.nih.gov; \\ Sekou F Traoré - cheick@mrtcbko.org; Tovi Lehmann* - tlehmann@niaid.nih.gov \\ * Corresponding author
}

Published: 22 March 2006

Malaria Journal 2006, 5:19 doi:10.1186/1475-2875-5-19

This article is available from: http://www.malariajournal.com/content/5/I/19

(c) 2006 Yaro et al; licensee BioMed Central Ltd.

This is an Open Access article distributed under the terms of the Creative Commons Attribution License (http://creativecommons.org/licenses/by/2.0), which permits unrestricted use, distribution, and reproduction in any medium, provided the original work is properly cited.
Received: 08 November 2005

Accepted: 22 March 2006

\begin{abstract}
Background: Knowledge of the ecological differences between the molecular forms of Anopheles gambiae and their sibling species, An. arabiensis might lead to understanding their unique contribution to disease transmission and to better vector control as well as to understanding the evolutionary forces that have separated them.
\end{abstract}

Methods: The distributions of hatching time of eggs of wild An. gambiae and An. arabiensis females were compared in different water types. Early and late hatchers of the $\mathrm{S}$ molecular form were compared with respect to their total protein content, sex ratio, development success, developmental time and adult body size.

Results: Overall, the distribution of hatching time was strongly skewed to the right, with $89 \%$ of the eggs hatching during the second and third day post oviposition, $10 \%$ hatching during the next four days and the remaining $1 \%$ hatching over the subsequent week. Slight, but significant differences were found between species and between the molecular forms in all water types. Differences in hatching time distribution were also found among water types (in each species and molecular form), suggesting that the eggs change their hatching time in response to chemical factors in the water. Early hatchers were similar to late hatchers except that they developed faster and produced smaller adults than late hatchers.

Conclusion: Differences in hatching time and speed of development among eggs of the same batch may be adaptive if catastrophic events such as larval site desiccation are not rare and the site's quality is unpredictable. The egg is not passive and its hatching time depends on water factors. Differences in hatching time between species and molecular forms were slight, probably reflecting that conditions in their larval sites are rather similar.

\section{Background}

Over $70 \%$ of the 500 million malaria cases that occur every year worldwide and even a higher fraction of the mortality burden are concentrated in tropical Africa [1].
Malaria transmission is driven by the mosquito vector system, which in most of sub-Saharan Africa consists of three primary species, namely Anopheles gambiae, Anopheles arabiensis and Anopheles funestus. Both An. gambiae and An. 
funestus are further subdivided into semi-isolated populations, typically referred to as forms [2-9]. The extent of genetic isolation between forms was studied extensively [10-13], but the mechanism of isolation and the driving forces are poorly understood. Associations between abundance of certain species and forms in relation to aridity and to rice cultivation have been observed $[5,6,14]$, but the adaptive differences between forms have yet to be identified [15].

The ecology of the egg of African anophelines is a neglected area of study. The conventional view is that hatching occurs as soon as the embryo completes its development $[16,17]$, which takes approximately two days in $27^{\circ} \mathrm{C}$ when the egg is kept on water. The time from oviposition to hatching of eggs of the molecular forms of An. gambiae and their sibling species, An. arabiensis was measured in different types of water. This distribution of hatching time was considered as a trait that affects the prospects of larval success had all of them hatched in the same time. If events such as short term desiccation of larval sites are likely, there may be an advantage to delayed hatching of some of the eggs, so they could hatch after the site is filled with water again as is the case in many floodwater species of Aedes and Psorophora. Similar to these culicines, eggs of the floodwater anopheline, An. diluvialis also spread their hatching in distilled water with less than $20 \%$ of the eggs hatching during the first $14 \mathrm{~d}$ post oviposition (p.o.). [18]. Eggs of An. gambiae can tolerate desiccation in humid conditions for several days $[19,20]$. Flooding of larval site, predator attack on hatching larvae, competition in crowded sites, etc. may also act as selective forces favouring delayed hatching of some of the eggs.

An. arabiensis and the molecular forms of An. gambiae mostly overlap in their larval sites when sympatric $[21,22]$, but some differences are known. In Mali and Burkina Faso, the $\mathrm{M}$ form predominates in permanent sites such as rice fields and much of its range covers dry savannas and the Sahel, where rain is less frequent and predictable than in wet savannas and forest areas, where the $\mathrm{S}$ form predominates [6]. An. arabiensis is also abundant in drier environments, but it is not common in rice cultivation areas in West Africa. These differences in the type of larval sites, lead us to predict that the hatch distribution varies between the species and the molecular forms.

\section{Materials and methods Mosquito collection}

Indoor resting mosquitoes were collected using aspirators during the end of October and early November 2004 from three villages in Mali: Donéguébougou (West 7 ${ }^{\circ} 59^{\prime} 5^{\prime \prime}$ longitude and North $12^{\circ} 48^{\prime} 38^{\prime \prime}$ latitude), located $15 \mathrm{~km}$ north of Bamako, Pimperena (West $5^{\circ} 42^{\prime}$ longitude and
North $11^{\circ} 28^{\prime}$ latitude), located $280 \mathrm{~km}$ southwest of Bamako, and Selingué (West $8^{\circ} 17^{\prime}$ longitude and North $11^{\circ} 42^{\prime}$ latitude), located $120 \mathrm{~km}$ south of Bamako. Mosquitoes were transported to the insectary at the Malaria Research and Training Center in Bamako, which maintains constant $27^{\circ} \mathrm{C}$ temperature and relative humidity of $75 \%$ to $85 \%$. The blood fed and gravid females were placed in one gallon cages and provided with sugar solution. On the third day after collection, each female was placed in a $50 \mathrm{ml}$ Falcon tube containing $15 \mathrm{ml}$ de-ionized water for oviposition. A strip of filter paper $(2 \mathrm{~cm}$ wide) surrounded the water edge to collect the eggs.

The species and the molecular form of each female (desiccated the morning after oviposition) was determined using PCR assays $[2,23]$. The eggs were counted on the filter paper, separated into groups of 40-50 eggs (exact count of each dish was recorded) and placed in a labeled Petri dish (50 mm diameter $\times 9 \mathrm{~mm}$ high) containing (i) rice field water, (ii) puddle water (iii) rock pool water, and (iv) de-ionized laboratory water. Egg batches with fewer than 80 eggs were excluded and egg batches with less than 120 or 160 eggs were used for two or three water types, respectively.

\section{Water collection}

Water was collected from natural larval sites that contained early (first and second) and late (third, fourth or pupae) instars of An. gambiae s.l. larvae. The rock pool water was collected from Banambani $(3 \mathrm{~km}$ from Donéguébougou). The depression in the rock (approximately $70 \mathrm{~cm}$ diameter and $20 \mathrm{~cm}$ deep), was covered with algae, but had no vegetation and the water, filled from a receding stream, was clear. The puddle and ricefield water were collected from Selingué. The puddle, filled with rain water was shrinking in size since the last rain fell 2-3 weeks before the first sampling. It measured approximately $2 \mathrm{~m}$ in diameter and $80 \mathrm{~cm}$ maximal depth at the first time it was sampled, and during the subsequent five days it shrunk to approximately $1.5 \mathrm{~m}$ diameter and $60 \mathrm{~cm}$ maximal depth. Its water was cloudy greenish with algae (no vegetation) and had high density of anopheline larvae. The rice field water was collected from shallow canal (approximately $300 \mathrm{~m}$ long, $50 \mathrm{~cm}$ wide and $25 \mathrm{~cm}$ deep) containing slow flowing clear water and surrounded by plants (up to $30 \mathrm{~cm}$ high above the water). Underwater vegetation was present as well. A two litre Thermos container was filled with water from each natural larval site every five days and kept in $7^{\circ} \mathrm{C}$ throughout the experiment. No attempt was made at chemical analysis of the various waters.

\section{Hatch distribution}

The Petri dishes containing the eggs were checked daily. If one or more first stage instar larvae (L1) were observed, 


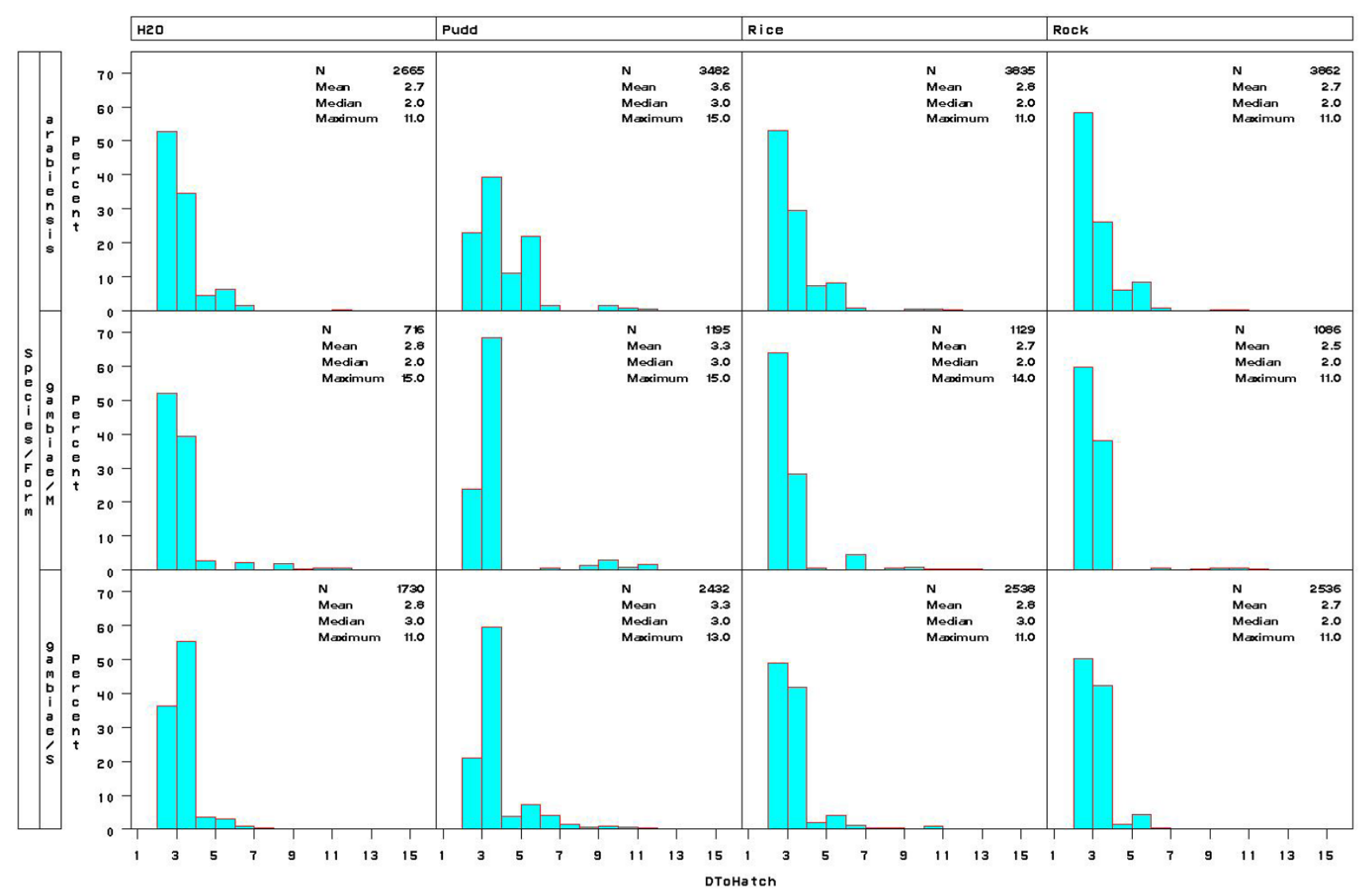

Figure I

Distribution of egg hatching times in different water types.

the dish was placed over a white background under illumination and photographed using a digital camera (HP Photosmart 945). Pictures were immediately evaluated to ensure that the image was clear and the Petri dish with its label of identification and time was fully included in the photograph. Counting of L1 was done on a computer screen. The number of eggs hatched on each day was calculated as the difference between the current and previous counts of L1. After the $7^{\text {th }}$ day p.o., newly hatched L1 were counted and removed by a Pasteur pipette. Water of the same source was added to the Petri dish every 4-5 days. The date of oviposition was considered to be the day before the egg batch was found.

\section{Early vs. late comparison}

Egg batches of a separate collection from Pimperena were used to compare larvae and adults produced by the eggs that hatched early and late. After the eggs were counted, they were placed in Petri dishes $(10 \mathrm{~cm}$ diameter $\times 2 \mathrm{~cm}$ high) with de-ionized water and were inspected every two hours, beginning in the second day p.o. for hatching. Newly hatched L1, less than two hours old, were counted and removed. Ten early hatchers (the last of every four L1) were preserved in $85 \%$ ethanol, and additional 30 (the first three of every four L1) were placed in a Petri dish (100 $\mathrm{mm}$ diameter $20 \mathrm{~mm}$ high) filled with $45 \mathrm{ml}$ de-ionized water and raised to adults as described below. Starting when approximately 50 eggs remained to hatch, the same procedure was repeated with the late hatchers. Collection of late hatchers ended when $40 \mathrm{~L} 1$ were obtained or after 36 hrs from the time the first L1 of this group was collected. In few cases, less than $30 \mathrm{~L} 1$ were obtained for the late hatchers group and the number of early hatchers group in that family was thinned to equal that of the late hatchers. The difference between the midpoint time between the beginning and end of the collection of L1 for each group (early vs. late) was calculated and families whose late hatchers were collected over 8 hrs after collection of the early hatchers were included in subsequent analyses. Larvae were fed daily 0.1 gram of ground Rich 
Table I: Hatching time of the eggs of An. arabiensis (A) and the molecular forms of An. gambiae (M and S) in different water types. Differences between forms in the same type of water are shown (see text for details).

\begin{tabular}{|c|c|c|c|c|c|c|c|c|}
\hline \multicolumn{2}{|l|}{ Water } & \multirow{2}{*}{$\begin{array}{l}\text { Species } \\
\text { Form }\end{array}$} & \multicolumn{3}{|c|}{ Hatch time (d) p.o. } & \multicolumn{3}{|c|}{$2 \mathrm{df} \chi 2$ tests $(* *=\mathrm{P}<0.0 \mathrm{I} * * *=\mathrm{P}<0.00 \mathrm{I})$} \\
\hline type & $\mathrm{N}$ & & $2-3$ & $4-7$ & $8-15$ & $M-S$ & $M-A$ & $S-A$ \\
\hline \multirow[t]{3}{*}{$\mathrm{dH} 2 \mathrm{O}$} & 2,665 & $A$ & 87.3 & 12.4 & 0.4 & $37.7^{* * *}$ & $85.2^{* * *}$ & $23.6 * * *$ \\
\hline & 716 & M & 91.3 & 5.0 & 3.6 & & & \\
\hline & 1,730 & $\mathrm{~S}$ & 91.6 & 7.8 & 0.6 & & & \\
\hline \multirow[t]{3}{*}{ Rice } & 3,835 & A & 82.6 & 16.4 & 1.1 & $12.1 * *$ & $100.9 * * *$ & $103.8^{* * *}$ \\
\hline & 1,129 & M & 92.2 & 5.2 & 2.6 & & & \\
\hline & 2,538 & $\mathrm{~S}$ & 90.1 & 7.6 & 1.5 & & & \\
\hline \multirow[t]{3}{*}{ Rock-pool } & 3,862 & A & 84.5 & 15.0 & 0.5 & $70.6 * * * *$ & $186.9 * * * *$ & $107.6 * * *$ \\
\hline & 1,086 & $M$ & 97.8 & 0.5 & 1.7 & & & \\
\hline & 2,536 & $S$ & 92.8 & 6.6 & 0.6 & & & \\
\hline \multirow[t]{3}{*}{ Puddle } & 3,482 & $A$ & 62.2 & 34.7 & 3.1 & $237.4 * * *$ & $548.4 * * *$ & $236.8 * * *$ \\
\hline & 1,195 & $M$ & 92.2 & 0.6 & 7.2 & & & \\
\hline & 2,432 & $S$ & 80.6 & 16.8 & 2.6 & & & \\
\hline Total & 27,206 & overall & 84.5 & 13.8 & 1.7 & & & \\
\hline $\begin{array}{l}\text { Total w/o } \\
\text { Puddle }\end{array}$ & 20,097 & overall & 88.4 & 10.6 & 1.0 & & & \\
\hline
\end{tabular}

Mix of TetraMin Fish Food. Pupae were collected daily and the date of adult emergence was recorded. Adults were preserved in $85 \%$ ethanol $24 \mathrm{hr}$ after emergence.

Adult body size was measured by its wing length (the distance from the alular notch to the wing's distal tip) using a dissecting scope fitted with a millimeter ruler at $20 \times$. A single wing was removed, spread over a small drop of water placed on a microscope slide, and covered with cover slip. All wings were measured to the nearest $0.1 \mathrm{~mm}$ using the same microscope and settings.

Total protein content of individual L1 was measured using the Micro BCA protein assay (Pierce Biotechnology, Rockford, IL). Individual L1 were dried using a speedvac prior to rotein extraction by subjecting the samples to two freeze-thaw cycles in $115 \mu \mathrm{l}$ of freshly prepared sodium hydroxide $(\mathrm{NaOH}, 50 \mathrm{mM})$ followed by 12 minutes of vortexing at medium speed (setting five out of 10). Following centrifugation for seven minutes at 14,000 rpm, $110 \mu \mathrm{l}$ of the supernatant were removed and used in determining protein concentration. Two replicate standard curves were prepared in the same solution using Albumin (provided with the Micro BCA kit). One hundred and ten microliters of the aqueous protein supernatant and standard curve samples, including two $\mathrm{NaOH}$ blanks, were loaded into individual microplate wells and processed according to the protocol provided with the Micro BCA assay kit. Cubic regression analysis was performed on the logarithm of the protein concentration and absorbance values to estimate the protein concentration of individual larvae based on the standard curve and blanks of each plate. Total larval protein content was calculated based on the volume in the colorimetric reaction and adjusted to the volume in the extraction. Data were analysed in SAS [24].

\section{Results \\ Hatch distribution}

Hatching time was measured for a total of 27,206 first instar larvae (L1) comprising 179 egg batches of 85, 32, and 62 of An. arabiensis, the $\mathrm{M}$, and the S molecular forms of An. gambiae, respectively. In each location one species or molecular form predominated. Thus, $98 \%$ of the A. arabiensis females were collected in Doneguebougou, $92 \%$ of the $\mathrm{M}$ form were collected in Selingue, whereas $86 \%$ of the $\mathrm{S}$ form were collected in Pimperena. Overall hatching rate was $86 \%$. The majority of eggs hatched on the second and the third days p.o. regardless of species, form and water types (Figure 1 and Table 1). However, hatching continued up to two weeks p.o., forming a distribution that is strongly skewed to the right (Figure 1). Late hatchers occurred in most egg batches (84\% of the egg batches had one or more eggs hatching at day five p.o. or later) rather than representing few exceptional egg batches. Overall, $89 \%$ of the eggs hatched during the first two days (second and third p.o.), $10 \%$ hatched during the next 4 days, and the remaining $1 \%$ hatched over the subsequent week (Figure 1 and Table 1).

To assess the differences in the hatching time between species and molecular forms at different water types, the hatch distribution was divided into three intervals (as described above, Table 1) and subjected to Chi square heterogeneity tests separately in each type of water. Because all four global tests were highly significant $\left(\chi^{2}>112, \mathrm{df}=\right.$ $4, \mathrm{P}<0.002)$, pair-wise tests were subsequently conducted and found to be significant as well (Table 1). In all water 
types, the molecular forms of An. gambiae appear more similar to each other compared with An. arabiensis in having a higher hatching rate during the early peak of hatching (day 2 and day 3 p.o.) than that of An. arabiensis. The main difference between the molecular forms was the higher hatching rate of the $\mathrm{S}$ form during the middle period of hatching (day 4 to day 7 ), whereas the $M$ form had higher hatching rate during the late period (day 8 to day 15). These differences between species and molecular forms were consistent in all water types (Table 1).

The difference between water types was tested in each species separately using contingency table heterogeneity tests (water type $\times$ hatching time interval) and found to be highly significant in all cases $\left(\chi^{2}>139\right.$, $\mathrm{df}=6, \mathrm{P}<0.001$, Figure 1 and frequencies are given in Table 1$)$. The hatching distribution was most distinct in puddle water (Figure 1 and Table 1). Because we used only one source of each type of water, these results provide no information on variation between water from the same type, e.g., different puddles or different rice fields, which may be as large, or larger than that measured here between the different water types. Nonetheless, these results suggest that eggs of these anopheline species change their hatching time according to water type.

\section{Comparison of early and late hatchers}

Early and late hatchers in 26 families of the S molecular form were compared with respect to their total protein content (measured in up to two-hour old L1 that hatched in laboratory deionized water), sex composition, developmental success, developmental time (from hatching to adult emergence) and the size of adults they produce (measured as wing length). Total protein content of early hatchers $(0.466 \mu \mathrm{g} / \mathrm{L} 1)$ was similar to that of late hatchers $(0.472 \mu \mathrm{g} / \mathrm{L} 1)$, and the difference was not significant (Wilcoxon sign paired test on family means, $\mathrm{n}=19, \mathrm{~S}=36, \mathrm{P}$ $>0.15)$. Females represented $55 \%$ of the total adults, but there was no difference in sex ratio between early and late hatchers $\left(\chi^{2}<1.9, \mathrm{df}=1, \mathrm{P}>0.15\right.$, not shown $)$. Development success of early hatchers $(78 \%)$ was similar to that of late hatchers $(83 \%)$ and the difference was not significant (Wilcoxon sign paired test by family, $\mathrm{n}=26, \mathrm{~S}=31.5$, $\mathrm{P}>0.4$ ). Developmental time of early hatchers was shorter than that of late hatchers (mean values: $10.3 \mathrm{~d}$ vs. $11.6 \mathrm{~d}$, respectively, Wilcoxon sign paired test by family, $\mathrm{n}$ $=26, \mathrm{~S}=175.5, \mathrm{P}<0.002)$. Finally, body size measured by wing length was smaller in early hatchers than in late hatchers for females (mean values of $2.96 \mathrm{~mm}$ vs. 3.10, respectively, Wilcoxon sign paired test by family, $\mathrm{n}=21, \mathrm{~S}$ $=87, \mathrm{P}<0.001$ ) and males (mean values of $2.82 \mathrm{~mm}$ vs. $2.92 \mathrm{~mm}$, respectively, Wilcoxon sign paired test by family, $\mathrm{n}=21, \mathrm{~S}=71, \mathrm{P}<0.01)$. These results suggest that the egg batch is not homogenous with respect to the attributes of the individual across different life stages.

\section{Discussion}

Although it lasts only a few days, the egg is an important part of the ecology of African anophelines that has been scarcely studied. The results reveal a complex pattern of hatching of eggs of field collected females and withinbatch heterogeneity in egg attributes that are expressed in the egg, larva, and adult stages. Contrary to the convention that the eggs of these anophelines hatch within two days, it was found that hatching spread over more than a week in many egg batches in all water types. In both species, $85-90 \%$ of the eggs hatched during the second and third days p.o., $10-14 \%$ hatched during the next 4 days, and the remaining $1-2 \%$ hatched over the following week. Whether this strategy is adaptive has yet to be determined, but the delayed hatching is potentially protective against the loss of the total batch had all eggs hatched together and experienced larval site desiccation or pathogen/predator attack. On the other hand, longer time to maturity exposes the aquatic stages to increased risk and delays reproduction, which carries clear disadvantages. In small larval sites, competition between larvae may favour staggered hatching, but the delay of mere $10 \%$ of the egg batch is unlikely to alleviate it greatly. Thus, the hatch distribution may represent an optimal strategy to balance the "desirable" rapid development into reproductive adults with the likelihood of various events leading to decreased larval success. Spread out hatching over time is clearly beneficial if all eggs are deposited in one or few sites, but it could remain beneficial even if females spread their egg batch over several larval sites if the likelihood of catastrophic events over short period is high. Studies to determine how females distribute their eggs over larval sites and the likelihood of catastrophic events such as larval site desiccation would be helpful to interpret this pattern. Instalment hatching, i.e., the spread of hatching over a series of inundations has long been recognized as a putative adaptation to larval site desiccation in floodwater species of Aedes and Psorophora with weeks or months between inundations [25-28]). Similar to these culicines, eggs of An. diluvialis (previously named Anopheles quadrimaculatus $\mathrm{C} 1$ ) that cohabits their larval sites, spread their hatching in distilled water with less than $20 \%$ of the eggs hatching during the first $14 \mathrm{~d}$ p.o., unless being subjected to a specific hatching stimulus such as vacuum[18]. Thus, delayed hatching in anophelines may be more common than previously believed.

Although sympatric molecular forms of An. gambiae and An. arabiensis cohabit many larval sites $[21,22,29]$ where their eggs have probably evolved under similar selective pressures, there are habitats that are exploited by one and not by the other form or species. For example, An. arabiensis (in East Africa) and the $M$ form of An. gambiae commonly use rice fields, whereas the $\mathrm{S}$ form is practically absent from rice fields but commonly found in temporary 
rain filled puddles [6]. On a larger geographical scale, $A n$. arabiensis and the $\mathrm{M}$ form inhabit dryer areas than those inhabited by the $\mathrm{S}$ molecular form. The differences in the hatch distribution between the molecular forms of $A n$. gambiae and between them and that of An. arabiensis may represent adaptive responses to different expectations of catastrophic events they tend to experience overall. Larger fractions of the eggs of An. arabiensis hatched late, consistent with its presence in dry habitats with higher likelihood of larval site desiccation. Knowledge of the occurrence of various catastrophic events (such as larval site desiccation) in different habitats can help evaluate the adaptive value of the observed hatch distribution. Whether different source of blood affect progeny traits is questionable. However in this region, indoor collections of An. arabiensis and the molecular forms of An. gambiae exhibited high $(>90 \%)$ human biting rate [30,31], thus it could not contribute to the variation reported here.

The effect different water types had on hatching time was especially pronounced with the puddle water. Further study is needed to determine whether the egg responds to certain signals that may indicate the likelihood of a catastrophe or to a stressful environment, which prolongs embryonic development. The water was collected from a puddle that had a high density of An. gambiae s.l. (and other culicids) larvae in it because it concentrated the larvae from considerably larger area in the course of drying out. Additionally, it was one of the few remaining puddles in the beginning of the dry season. It is possible that the delayed hatching in this water exhibited by all species and forms, was due to a signal the eggs could pick up from this water that signified a rapidly drying larval site. Eggs of many culicine species hatch in response to the reduced concentration of oxygen in the water [16]. Eggs of An. diluvialis hatch poorly in distilled water, but they hatch readily in swamp water and in response to unidentified organic chemicals in an extract from swamp soil [32].

Heterogeneity among eggs of the same batch was suggested by differences between early and late hatchers of the S molecular form. Eggs of Ae. taeniorhynchus and Ae. cantator showed heterogeneity among eggs in the same egg batch, with some of the eggs requiring exposure to cold temperature before hatching, and so delay their hatching to the next summer $[27,33]$. Although there was no difference between the early and late hatchers of $A n$. gambiae in their total protein content, as was their developmental success; late hatchers developed slower into adults and produced larger adults than early hatchers as was found for Ae. aegypti [34]. These differences suggest that the egg batch consists of individual larvae that are destined to develop in different ways to maximize various combinations of rapid development and adult size. This mixed strategy may be a response to the unpredictability of the conditions in the larval site. Accordingly, in larval sites with good nutrition and low risk of desiccation or predation, larvae that produce larger adults will have higher fitness despite their longer developmental time, but in sites of poor nutrition and high risk of predation those that develop faster will survive better and have higher fitness despite producing smaller adults. It cannot entirely be ruled out that the late hatchers developed into larger adults because of their density during the first $36 \mathrm{hr}$ of collection was lower due to our collection procedure (see Materials and methods). It is assumed that density effect at this early stage is unimportant. The association between hatching time and development time may reflect a developmental constraint, such as slow vs. fast growth and differentiation. Alternatively, it facilitates the shortest possible developmental time of the aquatic stage. Differences between early and late hatchers were described in a colony of Ae. aegypti [35], but the development time was shorter and sex ratio was biased towards females in late hatchers.

\section{Conclusion}

These results reveal that egg batches of An. gambiae and An. arabiensis consist of heterogenic individuals with respect to traits such as hatching time and larval development time. Slight but significant differences were found between the hatching time distributions of the molecular forms of An. gambiae and between them and that of $A n$. arabiensis. This similarity probably reflects that the larvae of both species and molecular forms are exposed to similar risks in their larval sites. The "programmed" hatching time can be changed by factors in the water. Further, the eggs in a single egg batch appear to follow different developmental plans. The variation in hatching time and in the larval development within an egg batch may help cope with the unpredictability of conditions in the larval site. Additional studies are needed to better characterize these egg traits, their evolutionary significance, physiological, and genetic basis as well as the stability in key conditions of larval sites.

\section{Authors' contributions}

ASY, AD, AA, and SFT carried out the field and laboratory experiments on the egg hatching and comparison of early and late hatchers. JMCR suggested and helped optimize the protein assay, which was performed by JEC. TL conceived the study and performed the statistical analysis. The experimental design was shaped by TL, ASY, SFT and RG. ASY and TL have written the ms with input from JMCR, JEC, and RG. All authors read the final version and approved it.

\section{Acknowledgements}

We thank the villagers of Donéguébougou, Pimpérena and Selingué for their kindness and generosity during mosquito collection in their houses. We thank Drs. Richard Sakai and Abdoulaye Diabate for helpful comments 
and suggestions on earlier versions of the manuscript and the Malian entomology team at MRTC for technical support. This research was supported by the Intramural Research Program of the NIH, NIAID.

\section{References}

I. Snow RW, Guerra CA, Noor AM, Myint HY, Hay SI: The global distribution of clinical episodes of Plasmodium falciparum malaria. Nature 2005, 434:214-217.

2. Favia G, Lanfrancotti A, Spanos L, Siden-Kiamos I, Louis C: Molecular characterization of ribosomal DNA polymorphisms discriminating among chromosomal forms of Anopheles gambiae s.s. Insect Mol Biol 200I, I 0:19-23.

3. Gentile G, Slotman M, Ketmaier V, Powell JR, Caccone A: Attempts to molecularly distinguish cryptic taxa in Anopheles gambiae s.s. Insect MolBiol 200I, 10:25-32.

4. della Torre A, Fanello C, Akogbeto M, Dossou-yovo J, Favia G Petrarca $V$, Coluzzi M: Molecular evidence of incipient speciation within Anopheles gambiae s.s. in West Africa. Insect MolBiol 2001, 10:9-18.

5. Coluzzi M, Petrarca V, Di Deco MA: Chromosomal inversion intergradation and incipient speciation in Anopheles gambiae. Bollettino di Zoologia 1985, 52:45-63.

6. Toure YT, Petrarca V, Traore SF, Coulibaly A, Maiga HM, Sankare O, Sow M, Di Deco MA, Coluzzi M: The distribution and inversion polymorphism of chromosomally recognized taxa of the Anopheles gambiae complex in Mali, West Africa. Parassitologia 1998, 40:477-511.

7. Costantini C, Sagnon N, Ilboudo-Sanogo E, Coluzzi M, Boccolini D: Chromosomal and bionomic heterogeneities suggest incipient speciation in Anopheles funestus from Burkina Faso. Parassitologia 1999, 41:595-611.

8. Dia I, Lochouarn L, Boccolini D, Costantini C, Fontenille D: Spatial and temporal variations of the chromosomal inversion polymorphism of Anopheles funestus in Senegal. Parasite 2000 7:179-184.

9. Lochouarn L, Dia I, Boccolini D, Coluzzi M, Fontenille D: Bionomical and cytogenetic heterogeneities of Anopheles funestus in Senegal. Trans R Soc Trop Med Hyg 1998, 92:607-6I2.

10. Cohuet A, Dia I, Simard F, Raymond M, Fontenille D: Population structure of the malaria vector Anopheles funestus in Senegal based on microsatellite and cytogenetic data. Insect $\mathrm{Mol} \mathrm{Biol}$ 2004, I 3:25 |-258.

II. Michel AP, Guelbeogo WM, Grushko O, Schemerhorn BJ, Kern M, Willard MB, Sagnon N, Costantini C, Besansky NJ: Molecular differentiation between chromosomally defined incipient species of Anopheles funestus. Insect Mol Biol 2005, | 4:375-387.

12. Tripet F, Toure YT, Taylor CE, Norris DE, Dolo G, Lanzaro GC: DNA analysis of transferred sperm reveals significant levels of gene flow between molecular forms of Anopheles gambiae. MolEcol 200I, 1 0:1725-1732.

13. Lehmann T, Licht M, Elissa N, Maega BT, Chimumbwa JM, Watsenga FT, Wondji CS, Simard F, Hawley WA: Population Structure of Anopheles gambiae in Africa. J Hered 2003, 94: I33-I47.

14. Coluzzi M, Sabatini A, Petrarca V, Di Deco MA: Chromosomal differentiation and adaptation to human environments in the Anopheles gambiae complex. Trans Roy Soc Trop Med Hyg 1979, 73:483-497.

15. Diabate A, Dabire RK, Kim EH, Dalton R, Millogo N, Baldet T, Simard F, Gimnig JE, Hawley WA, Lehmann T: Larval development of the molecular forms of Anopheles gambiae (Diptera: Culicidae) in different habitats: a transplantation experiment. J Med Entomol 2005, 42:548-553.

16. Clements AN: The Biology of Mosquitoes. Volume I. London: Chapman \& Halli; 1992.

17. Bates M: The natural history of mosquitoes. New York: MacMillan; 1949.

18. Jensen T, Kaiser PE, et al.: Adaptation to intermittently flooded swamps by Anopheles quadrimaculatus species CI (Diptera: Culicidae). Community and Ecosystem Ecology I994, 23: I I 50-I I 54.

19. Beier JC, Copeland RS, Oyaro C, Masinya A, Odago WO, Oduor S Koech DK, Roberts CR: Anopheles gambiae complex egg stage survival in dry soil from larval development sites in western Kenya. J Am Mosq Control Assoc 1990, 6:105-109.

20. Shililu JI, Maier WA, Seitz HM, Orago AS: Seasonal density, sporozoite rates and entomological inoculation rates of Anopheles gambiae and Anopheles funestus in a high-altitude sugarcane growing zone in Western Kenya. Trop Med Int Health 1998, 3:706-7io.

21. Edillo FE, Toure YT, Lanzaro GC, Dolo G, Taylor CE: Spatial and habitat distribution of Anopheles gambiae and Anopheles arabiensis (Diptera: Culicidae) in Banambani village, Mali. J Med Entomol 2002, 39:70-77.

22. Gimnig JE, Ombok M, Kamau L, Hawley WA: Characteristics of larval anopheline (Diptera: Culicidae) habitats in Western Kenya. J Med Entomol 200I, 38:282-288.

23. Scott JA, Brogdon WG, Collins FH: Identification of single specimens of the Anopheles gambiae complex by the polymerase chain reaction. Am J Trop Med Hyg 1993, 49:520-529.

24. SAS I, Inc: SAS for Windows Version 9.0. Ist edition. Cary, NC. Sas Institute; 2002.

25. Borg AF, Horsfall WR II, Hatching stimulus: Eggs of Floodwater Mosquitoes. Ann of the Ent Soc of America 1953, 46:472-478.

26. Breeland SG, Pickard E: Field Observations on twenty-eight broods of floodwater mosquitoes resulting from controlled floodings of a natural habitat in the Tennessee Valley. Mosquito News 1967, 27:343-358.

27. Moore RC, Bickley WE: Hatching of the eggs of Aedes Taeniorhynchus (Wiedemann) (Diptera: Culicidae) in response to temperature and flooding. Mosquito News 1966, 26:405-4I5.

28. Gillett JD: Variation in the hatching-response of Aedes eggs (Diptera: Culicidae). Bull Ent Res 1955, 46:255-265.

29. Minakawa N, Mutero CM, Githure JI, Beier JC, Yan G: Spatial distribution and habitat characterization of anopheline mosquito larvae in Western Kenya. Am J Trop Med Hyg 1999, 61:1010-1016.

30. Diatta M, Spiegel A, Lochouarn L, Fontenille D: Similar feeding preferences of Anopheles gambiae and A. arabiensis in Senegal. Trans R Soc Trop Med Hyg 1998, 92:270-272.

31. Dao A: Etude comparative des paramètres entomologiques de la transmission du paludisme dans différents villages de la préfecture de Kati En zone de savane soudanienne au Mali. University of Bamako, Mali; 2003.

32. Jensen T, Carlson DA, Barnard DR: Factor from swamp water induces hatching in eggs of Anopheles diluvialis (Diptera: Culicidae) mosquitoes. Environ Entomol 1999, 28:545-550.

33. Andreadis TG: Observations on installment egg hatching in the Brown Saltmarch mosquito, Aedes cantator. J Am Mosq Control Assoc 1990, 6:727-729.

34. Koella JC, Boete C: A genetic correlation between age at pupation and melanization immune response of the yellow fever mosquito Aedes aegypti. Evolution 2002, 56:1074-1079.

35. Hotchkin PG: The Duration of larval life of Aedes aegypti as affected by time of hatch. J Am Mosq Control Assoc 1985, I:489-492.

\section{Publish with Bio Med Central and every scientist can read your work free of charge}

"BioMed Central will be the most significant development for disseminating the results of biomedical research in our lifetime. "

Sir Paul Nurse, Cancer Research UK

Your research papers will be:

- available free of charge to the entire biomedical community

- peer reviewed and published immediately upon acceptance

- cited in PubMed and archived on PubMed Central

- yours - you keep the copyright
BioMedcentral 